Hydrol. Earth Syst. Sci., 15, 2275-2290, 2011

www.hydrol-earth-syst-sci.net/15/2275/2011/

doi:10.5194/hess-15-2275-2011

(C) Author(s) 2011. CC Attribution 3.0 License.

\title{
Snow cover dynamics and hydrological regime of the Hunza River basin, Karakoram Range, Northern Pakistan
}

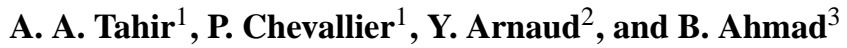 \\ ${ }^{1}$ Laboratoire Hydrosciences - UMR5569 (CNRS, IRD, Montpellier University 1\&2), CC57, Université Montpellier 2, \\ 34095, MONTPELLIER CEDEX 5, France \\ ${ }^{2}$ Laboratoire des Transferts en Hydrologie et Environnement - UMR5564 (CNRS, IRD, Université Joseph Fourrier, \\ Grenoble INP), LGGE, 54 rue Molière, Domaine Universitaire, BP 96, 38402, SAINT MARTIN d'HERES CEDEX, France \\ ${ }^{3}$ Director (Environment), Natural Resources Division, Pakistan Agricultural Research Council, G1/5, ISLAMABAD, Pakistan
}

Received: 24 February 2011 - Published in Hydrol. Earth Syst. Sci. Discuss.: 14 March 2011

Revised: 20 June 2011 - Accepted: 7 July 2011 - Published: 18 July 2011

\begin{abstract}
A major proportion of flow in the Indus River is contributed by its snow- and glacier-fed river catchments situated in the Himalaya, Karakoram and Hindukush ranges. It is therefore essential to understand the cryosphere dynamics in this area for water resource management. The MODIS MOD10A2 remote-sensing database of snow cover products from March 2000 to December 2009 was selected to analyse the snow cover changes in the Hunza River basin (the snow- and glacier-fed sub-catchment of the Indus River). A database of daily flows for the Hunza River at Dainyor Bridge over a period of $40 \mathrm{yr}$ and climate data (precipitation and temperature) for $10 \mathrm{yr}$ from three meteorological stations within the catchment was made available to investigate the hydrological regime in the area. Analysis of remotely sensed cryosphere (snow and ice cover) data during the last decade (2000-2009) suggest a rather slight expansion of cryosphere in the area in contrast to most of the regions in the world where glaciers are melting rapidly. This increase in snow cover may be the result of an increase in winter precipitation caused by westerly circulation. The impact of global warming is not effective because a large part of the basin area lies under high altitudes where the temperature remains negative throughout most of the year.
\end{abstract}

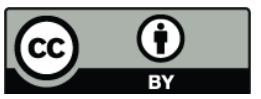

Correspondence to: A. A. Tahir (tahir@msem.univ-montp2.fr)

\section{Introduction and background}

An agricultural country, Pakistan is highly dependent on the Indus irrigation system, one of the largest irrigation networks in the world (SIHP, 1990). The Indus River emerges from the Tibetan Plateau and flows toward northern areas of Pakistan where it changes its direction toward the south and flows into the Arabian Sea (Fig. 1). It has a controlling storage at Tarbela dam as the river descends from the mountains. The catchment area upstream of Tarbela reservoir is called the Upper Indus River Basin (UIB) (Fig. 1), which contributes the main inflow to the main course of the Indus River at high elevations as a result of snow and glacier melt; the lower catchment is rain-fed. Tarbela is the first major structure on the Indus River and supplies the flow to the Indus Irrigation System to irrigate the agricultural lands of Punjab (a province of Pakistan), the dominant producer of agriculture products in the country. Inflow to Tarbela is measured at Besham Qila, situated approximately $80 \mathrm{~km}$ upstream of Tarbela (Fig. 2), with a mean annual flow of $2410 \mathrm{~m}^{3} \mathrm{~s}^{-1}$ (standard deviation for mean annual flow $=309 \mathrm{~m}^{3} \mathrm{~s}^{-1}$ ), according to the SWHP (Surface Water Hydrology Project) flow records from 1969 to 2008 .

The UIB has a total catchment area of $206000 \mathrm{~km}^{2}$ as calculated in this study. Nearly $11.5 \%$ of the total area $\left(22000 \mathrm{~km}^{2}\right)$ of the UIB is covered by perennial glacial ice including most of the largest valley glaciers, the largest area outside the polar and Greenland regions (Hewitt, 2001, 2007). The Greater Karakoram Range (Fig. 1), situated in UIB, has an extensive formation of glaciers due to high altitudes (Young and Hewitt, 1990), covering an area of $16300 \mathrm{~km}^{2}$ with about $13000 \mathrm{~km}^{2}$ of cover within Pakistan

Published by Copernicus Publications on behalf of the European Geosciences Union. 


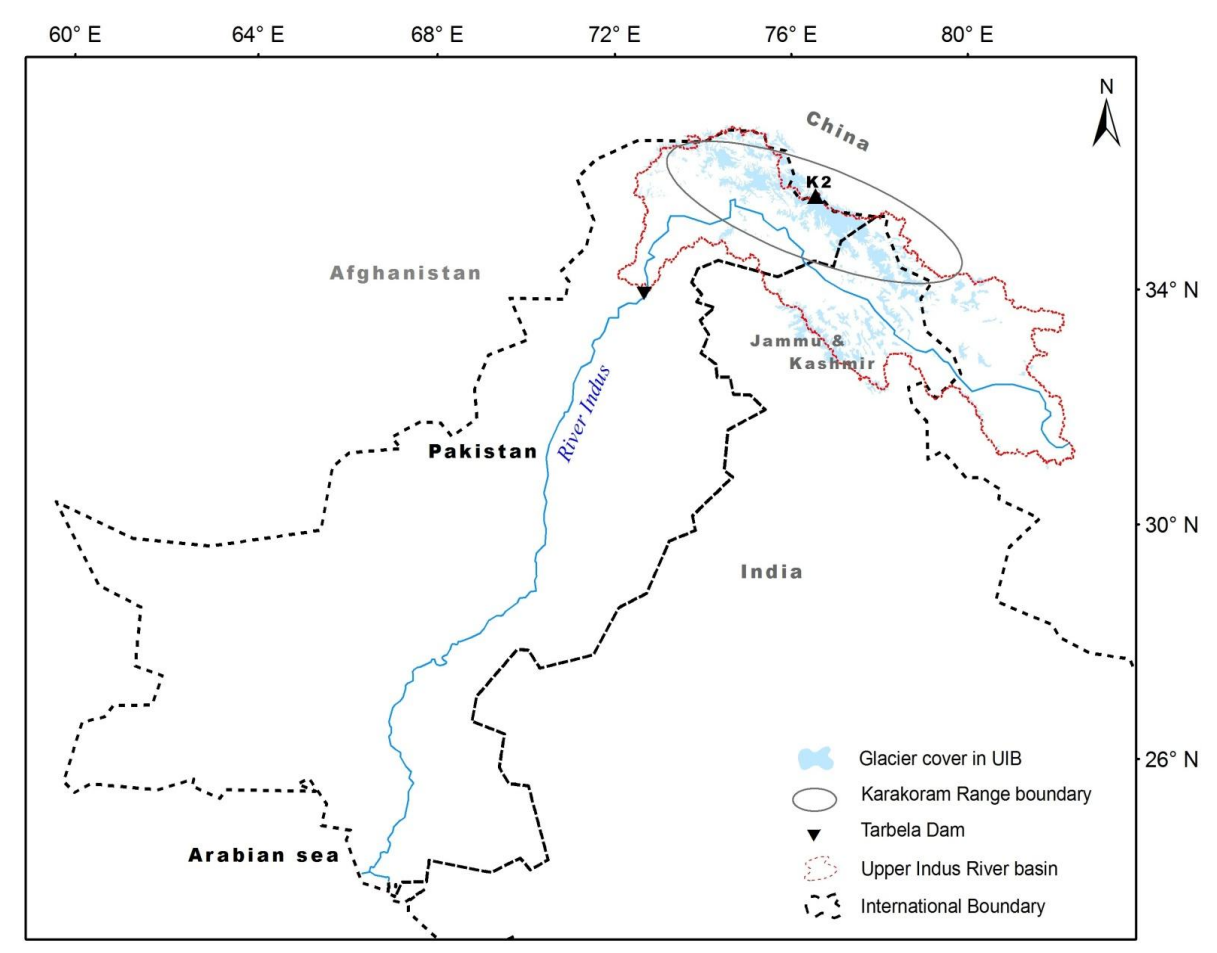

Fig. 1. Location of the Upper Indus River Basin (UIB) with main controlling storage at Tarbela Dam.

(Mercer, 1975). Most of the annual precipitation in the UIB falls in the winter and spring and originates from the west (Young and Hewitt, 1990). The high mountains of Hindukush-Karakoram-Himalaya (HKH) in the UIB decrease the effect of the monsoon in the catchment area, whose influence weakens northwestward; therefore, the climatic records in the UIB are different from the eastern Himalayas (Fowler and Archer, 2005; Young and Hewitt, 1990).

The main active hydrological zone for the Upper Indus River Basin is situated in the high-altitude Karakoram ranges. Archer (2003) explained that the Indus River catchment at Partab Bridge (Fig. 2) has nearly $36 \%$ of its area above $5000 \mathrm{~m}$ in elevation and is mainly fed by glaciers and snow melt in this area. Several authors (Hewitt et al., 1989; Wake, 1989; Young and Hewitt, 1990) reported that $80 \%$ of the flow of the Upper Indus River is contributed by less than $20 \%$ of its area, essentially from the zones of heavy snowfall and glacierised basins above $3500 \mathrm{~m}$ in elevation. Liniger et al. (1998) stated that some $90 \%$ of the lowland flow of the Indus River System originates from the Hindukush, Karakoram and western Himalaya mountain areas. Maurer et al. (2003) stated that the presence of snow in a river catchment area strongly affects the moisture that is stored at the surface and available for future runoff. The summer runoff is highly correlated with the summer mean temperature in these high-altitude sub-catchments of the UIB, mostly covered with permanent snow pack and glaciers (Archer, 2003). Linear regression analysis by Archer (2003) indicates that a
$1{ }^{\circ} \mathrm{C}$ rise in mean summer temperature would result in a $16 \%$ increase in summer runoff into the Hunza River.

Satellite image observation is very helpful in these remote regions of the world to examine cryosphere dynamics. Sirguey et al. (2009) reported that satellite remote sensing is a powerful tool to estimate the snow-covered area in remote and inaccessible areas. MODIS snow cover products have been widely used to estimate the snow cover area by researchers in several regions of the world. Tekeli et al. (2005) compared the MODIS snow cover images with ground observations and found that MODIS determined the snow cover satisfactorily even in the rough terrain river basin located in eastern Turkey. Maurer et al. (2003) found a significant improvement in snow cover determination using MODIS snow cover products, especially in topographically complex portions of the Columbia River basin, as compared to the operational NOHRSC (National Operational Hydrologic Remote Sensing Center) snow cover images. Immerzeel et al. (2009) investigated the effects of snow cover dynamics on the discharge of the Upper Indus River and concluded that stream flows can be predicted with a high degree of accuracy using MODIS snow cover data in a hydrological runoff model. Lee et al. (2005) reported that MODIS snow cover products have sufficient accuracy for stream flow prediction using the Snowmelt Runoff model (SRM) in the snowmelt-dominated basin of the Upper Rio Grande basin.

While the rapid melting of the ice cover is reported from High Asia, the Karakoram Range shows a more nuanced 


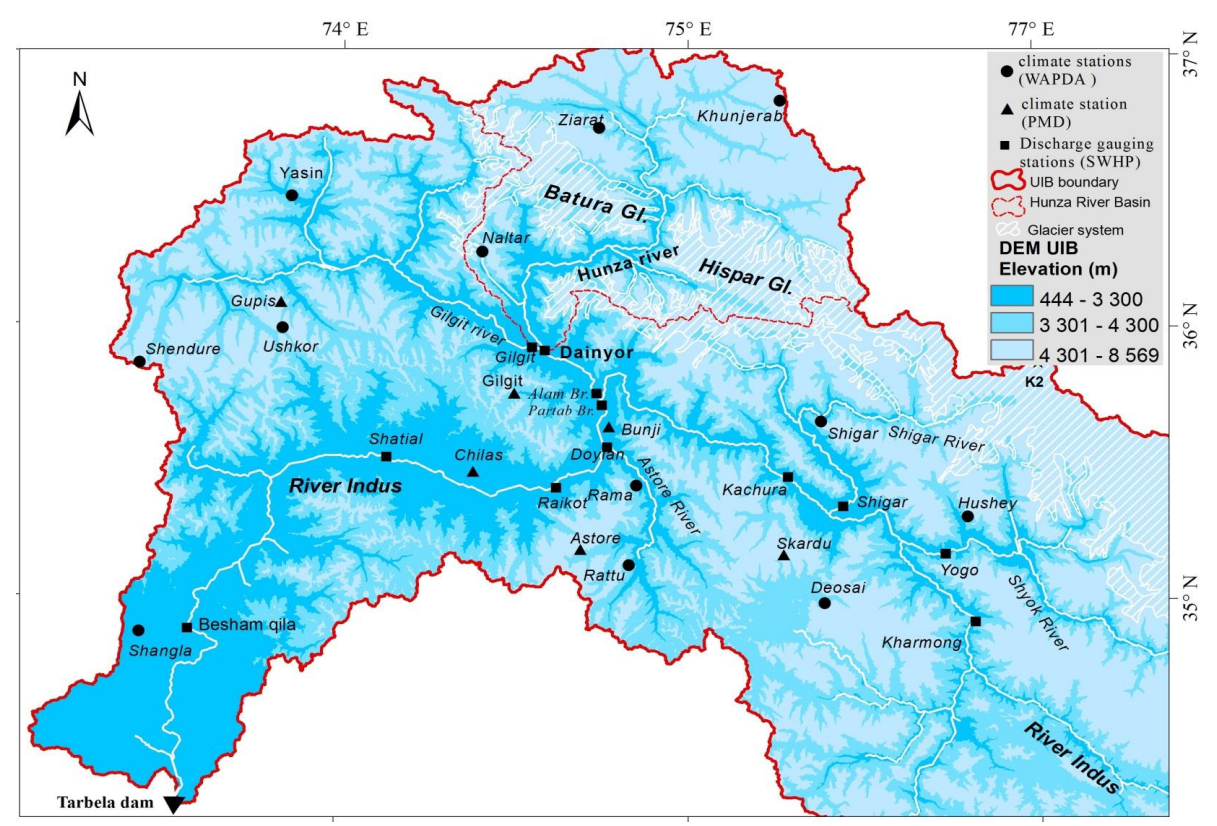

Fig. 2. ASTER Global digital elevation model (GDEM) of the Upper Indus River Basin and gauging station network within the boundary of Pakistan (Hunza River catchment location in the UIB is shown with a thin boundary line). The projection of the map is WGS1984 UTM $43 \mathrm{~N}$.

picture as highlighted by the IPCC's 4th synthesis report (IPCC, 2007). Hewitt (2005) reported that central Karakoram is the largest of those very few areas where expansion of glaciers has been noted. Some of the largest glaciers in the Karakoram Range have undergone rapid thickening since the mid-1990s; 13 glaciers of intermediate size $(10-20 \mathrm{~km}$ in length) and 16 high-altitude tributaries were observed to be advancing (Hewitt, 2005, 2007). These changes were observed only in the highest central parts of the Karakoram. This is contrary to most of the glaciers in the world reported to be shrinking for the last several decades, including the neighbouring Greater Himalaya analysed by Berthier et al. (2007). This contrast in glacier evolution shows a climate change pattern in Karakoram that differs from that in the Greater Himalaya (Fowler and Archer, 2006). Hewitt (2005, 2007) stated that a unique climate regime in this area and exceptionally high-altitude ranges of the ice masses may be the important factors in this expansion, contrary to other regions.

The management of Tarbela reservoir depends to a large extent on the summer inflow contributed by the snow- and glacier-fed tributaries situated in the Karakoram Range. The Hunza River at Dainyor Bridge is representative of the moderately high runoff catchments in the centre of the Karakoram where a significant proportion of the flow is derived from cryosphere melt. It nearly doubles the runoff rate along with the Gilgit River in the overall Indus catchment at Partab Bridge station (Fig. 2), i.e. at its confluence point with the Indus River. It is, therefore, important to monitor the seasonal snow cover in snow-fed catchments for several purposes such as hydrometeorology, flood forecasting and water resource management. This study is the first to detail and to investigate the cryosphere dynamics based on the remotely sensed MODIS snow cover data (MOD10A2) over a period of $10 \mathrm{yr}$ in the Hunza River basin (situated in the central Karakoram region). The main objectives of this study were to investigate:

1. The climate variations within the Hunza River basin;

2. The relevance and validity of remotely sensed MODIS snow cover data in the catchment;

3. The hydrological behaviour of the catchment in response to climate variables (precipitation and temperature);

4. The cryosphere dynamics and impact of climate change on the cryosphere in the high-elevation mountainous Hunza River basin;

5. The annual and seasonal correlation between snow cover, mean temperatures and stream flow in the Hunza River basin.

The study area is described in Sect. 2 of this paper followed by the description of the data sets and analysis of the data in Sect. 3. The results obtained from this study are described and discussed in Sect. 4. Section 5 presents the conclusions drawn from this study. 
Table 1. Characteristics of the study area (Hunza River basin).

\begin{tabular}{ll}
\hline River flow gauging station & Dainyor Bridge \\
\hline Latitude & $35^{\circ} 56^{\prime} \mathrm{N}$ \\
Longitude & $74^{\circ} 23^{\prime} \mathrm{E}$ \\
Elevation of gauging station & $1450 \mathrm{~m}$ \\
Drainage area & $13733 \mathrm{~km}^{2}$ \\
Glacier-covered area & $4688 \mathrm{~km}^{2}$ (Akhtar et al., 2008) \\
Glacier cover percentage & $34 \%$ \\
Mean elevation (computed from & $4631 \mathrm{~m}$ \\
ASTER GDEM) & \\
Area above 5000 m & $32.5 \%$ \\
No. of meteorological stations & 3 (Installed by WAPDA) \\
\cline { 2 - 3 } & Khunjerab Ziarat Naltar \\
& $4730 \mathrm{~m} \quad 3669 \mathrm{~m} \quad 2858 \mathrm{~m}$
\end{tabular}

\section{Study area (Hunza River basin)}

The present analysis of cryosphere dynamics was undertaken in the Hunza River basin (basin area, $13733 \mathrm{~km}^{2}$ ) (Fig. 2), situated in the high mountainous region of central Karakoram, with approximately $4463 \mathrm{~km}^{2}$ of catchment area at an elevation over $5000 \mathrm{~m}$. The area distribution in different elevation bands in the catchment is shown by the hypsometric curve in Fig. 3.

Some key features of the Hunza River basin are given in Table 1 . The snow cover area in winter is approximately $80 \%$ and decreases to $30 \%$ in summer. The mean total annual precipitation is $170 \mathrm{~mm}$ at Khunjerab $(4730 \mathrm{~m}), 22 \mathrm{~mm}$ at Ziarat $(3669 \mathrm{~m})$ and $680 \mathrm{~mm}$ at Naltar $(2858 \mathrm{~m})$ according to the 10-yr record (1999-2008) of the three climatic stations in the catchment. The Hunza River has a mean annual flow of $323 \mathrm{~m}^{3} \mathrm{~s}^{-1}$ (i.e. $742 \mathrm{~mm}$ of water depth equivalent) gauged at Dainyor Bridge (Fig. 2), according to the 40-yr (1966-2008) flow record of the SWHP-WAPDA. However, the present precipitation records are not representative of the runoff at the outlet. There are two main explanations for this problem.

(1) The most active hydrological region for the Hunza River lies above $5000 \mathrm{~m}$ in elevation where maximum snowfall and accumulation occurs, as confirmed by Young and Hewitt (1990). All the major meteorological stations of the region are located below this altitude range and we have no data records of the water equivalent of the snow accumulation in this elevation zone. Hewitt $(2005,2007)$ reported that there is a five- to tenfold increase in precipitation over the elevation of $5000 \mathrm{~m}$, and a large drop in temperature. Hewitt (2007) stated that about $90 \%$ of the total glaciated area in the Karakoram Range lies between 5000 and $6000 \mathrm{~m}$, where most of the accumulation zones lie. The Karakoram Range receives maximum precipitation at elevations greater than $3500 \mathrm{~m}$ (Hewitt, 1986). Precipitation in the form of snow contributes the large moisture surplus for the UIB (Wake, 1989). The Batura Glacier Investiga- tion Group, BGIG (1976) recorded a net winter accumulation of $1030 \mathrm{~mm}$ water equivalent (w.e.) at $4840 \mathrm{~m}$ on Batura Glacier situated in the Hunza River basin. An annual snow accumulation ranging from $900 \mathrm{~mm}$ to $1900 \mathrm{~mm}$ w.e. in the 4900- to 5400-m elevation range was reported by Hewitt et al. (1989) and Wake (1989) in the Biafo Glacier basin of the Karakoram Range. Winiger et al. (2005) derived the total annual precipitation for different altitudinal zones using a combined snow cover and ablation model. The estimated precipitation for northwest Karakoram was more than $1700 \mathrm{~mm} \mathrm{yr}^{-1}$ above $5500 \mathrm{~m}$.

(2) The other factor that marks this contrast is the fact that the precipitation gauges present at high altitudes can catch only $20-30 \%$ of the precipitation, while the rest is distributed outside the gauges by strong winds. This factor may be the reason for the low precipitation level recorded at the Khunjerab climate station situated just below $5000 \mathrm{~m}$ in elevation. According to Sevruk $(1985,1989)$ and Førland et al. (1996), the greatest of the systematic errors in precipitation gauging is wind-induced error (flow distortion), especially in the case of snowfall where losses can be on average 10-50\%, despite the many gauges equipped with wind shields.

\section{Data: sources and analysis}

\subsection{Topography}

The Advanced Spaceborne Thermal Emission and Reflection Radiometer (ASTER), Global Digital Elevation Model (GDEM) was used to delineate the catchment boundary studied. The ASTER GDEM is available for high-latitude and steep mountainous areas not covered by SRTM3 (METI and NASA, 2009). It is based on ASTER images (see Sect. 3.3).

Nine downloaded ASTER GDEM tiles were mosaicked and then treated further using the standard GIS techniques to delimit the Hunza River basin. The study area was then extracted and superimposed by the gauging stations and other necessary feature layers. Three different altitudinal zones were extracted from the GDEM study area for detailed analysis of snow cover distribution. Each of the three zones contains one climate station so we can study each zone snow cover change in relation to its own climate. The characteristics of these zones are given in Table 2.

\subsection{Hydrometeorology}

The database of daily flows for the Hunza River gauged at Dainyor Bridge was made available for this analysis from 1966 to 2008, with deficient data from 2005 to 2007. Stream flow measurement in Pakistan is mostly carried out by the Surface Water Hydrology Project of the Water and Power Development Authority (SWHP-WAPDA), with the earliest records beginning in 1960. Daily mean flows have been published in annual reports and have been checked and 


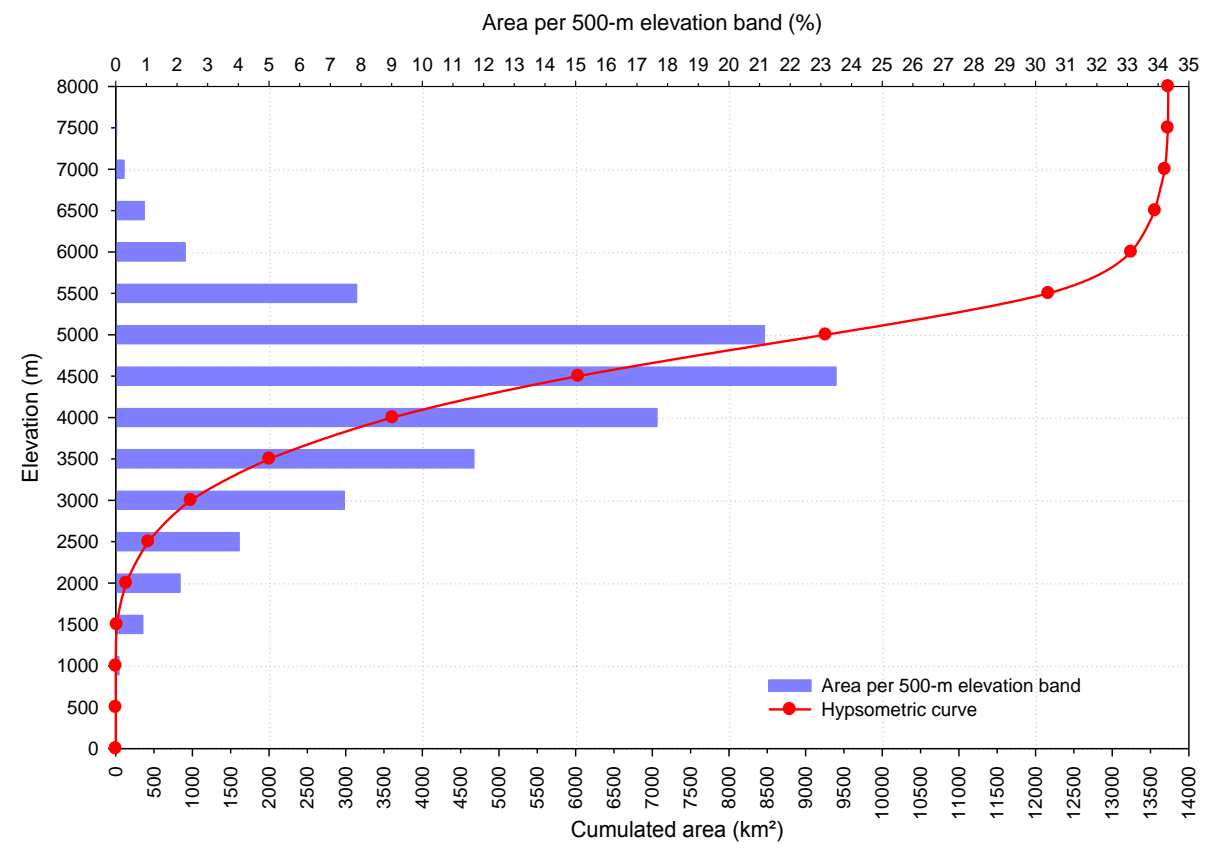

Fig. 3. Hypsometric curve of the Hunza River basin and distribution of the area by layer under each 500-m elevation band.

Table 2. Characteristics of the three elevation zones extracted from the GDEM of the Hunza River basin and their corresponding climate station.

\begin{tabular}{lccccl}
\hline Zone & Elevation range $(\mathrm{m})$ & Mean elevation $(\mathrm{m})$ & Area $(\%)$ & Area $\left(\mathrm{km}^{2}\right)$ & Climate station \\
\hline A & $1432-3300$ & 2365.5 & 11 & 1541 & Naltar \\
B & $3301-4300$ & 3800.5 & 25 & 3413 & Ziarat \\
C & $4301-7849$ & 6075.0 & 64 & 8779 & Khunjerab \\
\hline Total & & & $100 \%$ & 13733 & \\
\hline
\end{tabular}

Elevation range and mean elevation for each zone was computed from ASTER global digital elevation model (GDEM).

digitised in a database prepared by the German Technical Development Agency (GTZ) acting as advisors to WAPDA.

The temperature and precipitation records at Gilgit just outside the basin have been used by the researchers in past years for testing runoff controls because there were no climatic stations within the basin. We used the meteorological data available, at the Gilgit climate station for almost 50-yr period and at three high-altitude stations (Fig. 2 and Table 1) from 1999 to 2008 within the Hunza River basin established by WAPDA, although the records for these data were not particularly long $(\sim 10 \mathrm{yr})$.

The available hydrological and meteorological data were entered in the Hydraccess database, IRD, developed by Vauchel (2005), for easy use in the future. Regression analysis was performed on the climate data (temperature and precipitation) available at high-altitude stations (Naltar, Ziarat and Khunjerab) within the Hunza basin and the Gilgit climate station (Fig. 2) just outside the catchment boundary, to investigate the climate correlations between these stations.
Regression analysis was also performed between annual and seasonal (summer and winter) stream flow data at Dainyor and climate data from the Hunza basin climate stations and the Gilgit station to identify the climate station that was the most representative of discharge at Dainyor. Moreover, this analysis was performed to investigate the main controlling factors of runoff for the Hunza River at Dainyor Bridge. The Pearson correlation (Rodgers and Nicewander, 1988) and Kendall rank correlation (Kendall, 1975; Kendall and Gibbons, 1990) tests were used to evaluate the relationship between different hydrological and climate variables of all the gauging stations mentioned above.

\subsection{Snow cover}

The Moderate Resolution Imaging Spectroradiometer (MODIS) snow products were selected to calculate the snow cover percentage on our study area. The MODIS/Terra Snow Cover 8-Day L3 Global 500 m Grid (MOD10A2) 
used for this study contains data fields for maximum snow cover extent over an 8-day repeated period (Hall et al., 2006, updated weekly) and has a resolution of approximately $500 \mathrm{~m}$ covering the Hunza River basin completely. A data set of 450 processed MOD10A2 (V005) images available from March 2000 to December 2009 was downloaded from http://nsidc.org/cgi-bin/snowi/search.pl.

The available MODIS images, from the 2000-2009 period on an 8-day classification basis, were mosaicked and projected with the WGS 1984 UTM ZONE 43N projection system. The Hunza River basin area was then extracted from this mosaicked scene to assess the snow and ice cover (cryosphere) percentage in the study area over a $10-y r$ period. When the percentage of cloud cover exceeded $20 \%$ on a specific date, the record was eliminated and the average snow cover on this date was estimated by interpolating linearly between the previous and the next available cloudfree images. The snow cover area was also calculated for the different altitudinal zones to investigate the snow cover dynamics in these zones over a period from 2000 to 2009. A version of non-parametric Mann-Kendall trend test for the seasonal/periodic data (Hirsch et al., 1982; Hirsch and Slack, 1984) was applied to identify the trends in time series data; the values of this trend test are represented by Kendall's tau $(\tau)$ coefficient.

Higher-spatial resolution ASTER (Advanced Spaceborne Thermal Emission and Reflection Radiometer) images were used for snow cover extent extraction to validate MODIS snow cover products. The ASTER instrument operates in different spectral regions that have $15-\mathrm{m}, 30-\mathrm{m}$ and $90-\mathrm{m}$ spatial resolutions (Lopez, 2007; Sarwar and Bill, 2003). Four ASTER images, nearly cloud-free, in different seasons, were downloaded from http://glovis.usgs.gov/ for use in this study. The dates of these images are 16 July 2000, 30 April 2001, 26 June 2001 and 28 February 2002. The validation was done by comparing the images from ASTER and MODIS snow cover products on the same dates. As an additional analysis, these satellite images were sliced into three elevation zones (description of these zones is given in Table 2) to investigate the sensibility of MODIS snow cover data at different altitudes and slopes.

The Normalized Difference Snow Index (NDSI) has been widely used for effective snow cover mapping using various sensors (Dankers and de Jong, 2004; Nagler et al., 2008; Sirguey et al., 2008; Hall et al., 2002). The NDSI was applied to the ASTER images to enhance the snow cover extent. The aim of this spectral index is to enhance the snow and ice targets and distinguish them from vegetation, bare ground and clouds. The NDSI index does not differentiate between snow and snow-covered ice as stated by Lopez (2007), so both of them are included in the results obtained with the NDSI.

\section{Results and discussion}

\subsection{Climate data variation analysis}

Correlation coefficient values for the trend of different climate variables (monthly temperatures and precipitation) between the Hunza basin climate stations and the Gilgit climate station are given in Table 3. Pearson and Kendall rank correlation tests (significance level, $p=5 \%$ ) were applied to evaluate the relationship between these variables. A highly significant correlation was found for maximum, minimum and mean temperature trends between all the stations of the Hunza basin and the mean temperatures at the neighbouring Gilgit climate station. The correlation coefficient value was at least 0.97 in each case. Regression analysis of seasonal and annual temperatures at three Hunza basin climate stations ranging in elevation from $2858 \mathrm{~m}$ to $4730 \mathrm{~m}$ gives lapse

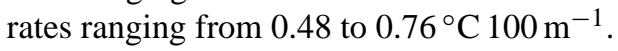

As discussed before, the absolute values of precipitation are significantly underestimated and cannot be exploited in the framework of the hydrological balance. Nevertheless we took as a hypothesis that for the same precipitation gauge the observations are relatively consistent and they records give us the relative trend of precipitation from one month to other. Therefore, the correlation is carried out for the distribution of precipitation from one month to other and not for the volume. Correlation coefficient values for monthly precipitation show that there is a significant correlation between the Hunza basin climate stations (Table 3). A maximum correlation was found between Ziarat and Naltar $(r=0.37)$. The minimum correlation for monthly precipitation was found between Ziarat and Khunjerab $(r=0.25)$. Almost the same behaviour was shown by the monthly precipitation correlation between the Gilgit climate station and the Hunza valley stations and a maximum significant correlation $(r=0.62)$ was found between the Gilgit and Naltar climate stations. These correlations are made between short data series available from the Hunza climate stations and results based on this should be verified with long data series (once available) in the future.

The altitude within the Hunza River basin varies greatly, which is why the climate records at different stations within the basin are not strongly correlated. Moreover, the Hunza basin climate stations are situated at much higher altitudes than the Gilgit station and therefore better represent the climate records (temperature, precipitation, etc.) of the Hunza River basin at different varying elevations. Nearly $98 \%$ of the Hunza River basin has an elevation greater than $2000 \mathrm{~m}$ and the Gilgit station $(\sim 1460 \mathrm{~m})$ does not suitably represent the high-altitude climate conditions of the catchment, which receives much more snow at high altitudes than the Gilgit River basin. 
Table 3. Monthly climate data (precipitation and temperature) correlation coefficients between three climate stations of the Hunza River basin (1999-2007) and Gilgit climate station (1999-2007).

\begin{tabular}{|c|c|c|c|c|c|c|c|}
\hline Precipitation & \multicolumn{3}{|c|}{ Ziarat } & \multicolumn{3}{|c|}{ Naltar } & Gilgit \\
\hline Khunjerab & \multicolumn{3}{|c|}{$0.25(0.32)$} & \multicolumn{3}{|c|}{$0.33(0.26)$} & $0.29(0.33)$ \\
\hline Ziarat & & & & \multicolumn{3}{|c|}{$0.37(0.31)$} & $0.38(0.29)$ \\
\hline Naltar & & & & \multirow{2}{*}{\multicolumn{3}{|c|}{-}} & $0.62(0.47)$ \\
\hline Mean precipit & tion in the $\mathrm{Hu}$ & za River basi & & & & & $0.62(0.45)$ \\
\hline \multirow[t]{2}{*}{ Temperature } & \multicolumn{3}{|c|}{ Ziarat } & \multicolumn{3}{|c|}{ Naltar } & Gilgit \\
\hline & $T_{\max }$ & $T_{\min }$ & Mean $T$ & $T_{\max }$ & $T_{\min }$ & Mean $T$ & $T_{\mathrm{avg}}$ \\
\hline Khunjerab & $0.99(0.92)$ & $0.97(0.88)$ & $0.99(0.92)$ & $0.99(0.92)$ & $0.99(0.92)$ & $0.99(0.92)$ & $0.98(0.88)$ \\
\hline Ziarat & - & - & & $0.99(0.92)$ & $0.97(0.89)$ & $0.99(0.92)$ & $0.98(0.87)$ \\
\hline Naltar & & & - & - & - & - & $0.99(0.88)$ \\
\hline \multicolumn{7}{|c|}{ Avg. of Hunza basin climate stations mean temperature } & $0.98(0.88)$ \\
\hline
\end{tabular}

$T_{\max }=$ Daily maximum temperature, $T_{\min }=$ Daily minimum temperature, Mean $T=$ Daily mean temperature, $T_{\text {avg }}=$ Monthly mean temperature. Values outside and within the ( $)$ are Pearson and Kendall rank correlation coefficient values, respectively. All the values are different from 0 with $p=0.05$.

\subsection{MODIS snow cover product validation}

The snow cover area on cloud-free ASTER images was compared with MODIS snow cover images on the same dates (seasonally significant) to validate the MODIS snow cover product as given in Table 4. The validation was done for the total as well as for zone-wise snow cover area of the images. The results obtained for the validation of MODIS images with ASTER images (which have higher-spatial resolution than MODIS) suggests that MODIS snow products are reliable in estimating the snow cover area in the Hunza River basin. The zone-wise comparison suggests that the low-elevation, high-relief areas have a larger mismatch than the higher-elevation, lower relief areas. The NDSI was applied to ASTER images and the index (threshold) values greater than or equal to 0.82 were considered as snow and ice cover. The index value was calibrated by visual and pixel inspection of two ASTER and MODIS images. In comparison, the index value of 0.9 was used to calculate the snow cover extent from ASTER images over the Pamir region (Afghanistan) by Haritashya et al. (2009). Comparison of MODIS (MOD10A2) image and ASTER images taken on 28 February 2002 (Fig. 4) showed nearly the same percentage of snow cover area. MOD10A2 snow products are 8-day averages and the time span of this particular MODIS snow product (compared with ASTER in Fig. 4) is from 25 February 2002 to 4 March 2002.

\subsection{Hydrological behaviour of the Hunza River basin}

The Pearson and Kendall rank correlation coefficient values ( $p=5 \%$ ) obtained for the correlation between annual and seasonal stream flow at Dainyor and the climate data from the Hunza basin climate stations and the Gilgit station are given in Table 5. No significant correlation was found between annual precipitation of all the climate stations analysed and the stream flow at Dainyor Bridge. The maximum correlation coefficient value was found between annual precipitation at Khunjerab and runoff at Dainyor $(r=0.26)$. Hewitt et al. (1989) and Wake (1989) stated that the annual precipitation for Hunza River basin above $5000 \mathrm{~m}$ in elevation is on the order of 1800-2000 mm. This elevation and precipitation are instrumental in creating large glaciers and perennial snow, which slowly moves down to the ablation zone and contributes to the river flow in summer. An analysis of seasonal runoff and precipitation showed no significant correlation between summer precipitation and runoff at Dainyor for almost all the climate stations, as given in Table 5. A significant inverse correlation was found between summer precipitation at Gilgit and runoff at Dainyor $(r=-0.22)$. The reason for this negative correlation is associated to more precipitation and increased cloudiness which leads to less incoming short wave radiation and higher albedos due to fresh snowfall and therefore less energy available for snowmelt resulting in lower discharges (Archer, 2003). This may also be attributable to the minimum effect of the monsoon regime in the Hunza basin because of the Karakoram high mountainous barrier.

Analysis of correlation coefficient values suggests that there is a significant positive correlation between the annual and seasonal temperature records and discharge at Dainyor (Table 5), which indicates that river flows are driven by snowmelt (resulting by the increase in mean temperature) in the catchment. This fact is explained by Archer (2003) that the peak seasonal (summer) and daily flows in the Karakoram region are caused by the availability of heat energy which melts the snow pack and the water stored in the form of snow and ice. The maximum correlation coefficient value $(r=0.79)$ was found for annual correlation between runoff at Dainyor and mean temperatures at Khunjerab, Ziarat and 
Table 4. Comparison of zone-wise and total snow cover area on MODIS and ASTER images for validation of MODIS images. (The main characteristics of the elevational zones are given in Table 2).

\begin{tabular}{|c|c|c|c|c|c|}
\hline \multirow{2}{*}{ Date of images } & \multirow{2}{*}{ Elevation zone } & \multicolumn{2}{|c|}{ Zone-wise snow cover area $(\%)$} & \multicolumn{2}{|c|}{ Total snow cover area $(\%)$} \\
\hline & & MODIS & ASTER & MODIS & ASTER \\
\hline \multirow{3}{*}{16 July 2000} & A & 9 & 1 & \multirow{3}{*}{34} & \multirow{3}{*}{33} \\
\hline & $\mathrm{B}$ & 6 & 3 & & \\
\hline & $\mathrm{C}$ & 57 & 59 & & \\
\hline \multirow{3}{*}{30 April 2001} & A & 5 & 4 & \multirow{3}{*}{65} & \multirow{3}{*}{63} \\
\hline & $\mathrm{B}$ & 32 & 24 & & \\
\hline & $\mathrm{C}$ & 88 & 88 & & \\
\hline \multirow{3}{*}{26 June 2001} & A & 0 & 2 & \multirow{3}{*}{30} & \multirow{3}{*}{32} \\
\hline & $\mathrm{B}$ & 10 & 11 & & \\
\hline & $\mathrm{C}$ & 62 & 64 & & \\
\hline \multirow{3}{*}{28 February 2002} & A & 29 & 41 & \multirow{3}{*}{84} & \multirow{3}{*}{85} \\
\hline & $\mathrm{B}$ & 75 & 74 & & \\
\hline & $\mathrm{C}$ & 97 & 96 & & \\
\hline
\end{tabular}

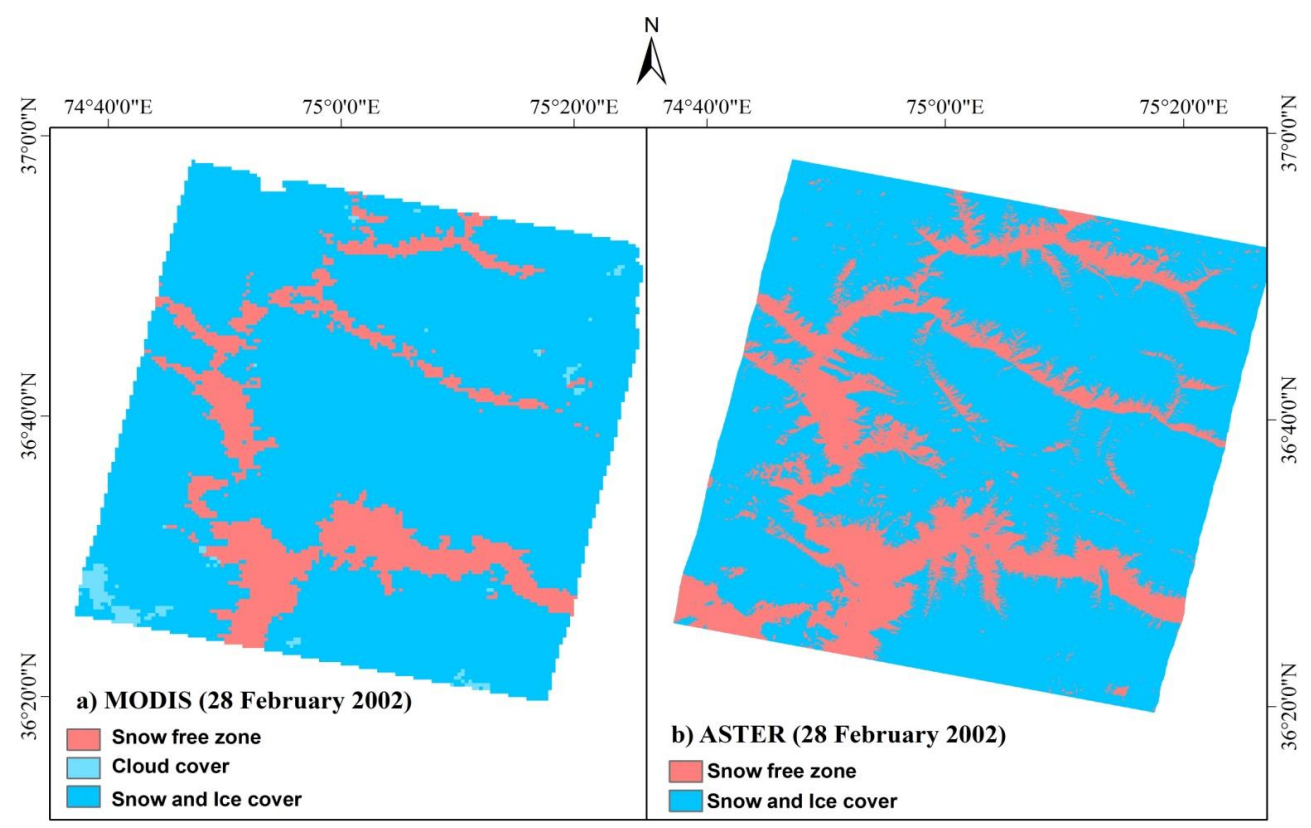

Fig. 4. (a) MODIS snow cover image and (b) ASTER snow cover image for the Hunza River basin. MODIS (MOD10A2) snow product is 8-day average data and the time span of this particular image presented here is from 25 February 2002 to 4 March 2002.

Gilgit. For summer temperature and runoff, the Gilgit climate station (situated outside the basin) showed a strongly significant correlation $(r=0.89)$. Khunjerab $(r=0.81)$ and Ziarat $(r=0.81)$ (situated within the basin) also had significant positive correlations with runoff at Dainyor. The correlation coefficient between winter and spring temperatures and runoff was also found to be significantly positive and the coefficient value was not less than 0.61 for any station. This result can also be explained by the fact that snow and ice melt are driven by short wave (SW) and long wave (LW) energy balance at the surface in early spring and summer (Sicart et al., 2005, 2006) and a higher air temperature is only one of the outcomes of this balance. Moreover, the climate variables (temperature and precipitation) observed at all the climate stations in the Hunza River basin are almost as well correlated with Hunza river runoff as the Gilgit climate station variables (Table 5). 
Table 5. Annual and seasonal correlation coefficients between stream flow data at Dainyor (1999-2007) and (a) daily climate data (precipitation and temperature) of Hunza basin climate stations (1999-2007), (b) monthly climate data (precipitation and temperature) of Gilgit station (1999-2007).

\begin{tabular}{|c|c|c|c|}
\hline \multirow[t]{2}{*}{ Climate data } & \multicolumn{3}{|c|}{ Stream flow in Hunza River at Dainyor Bridge } \\
\hline & $\begin{array}{r}\text { Annual correlation } \\
\text { (January to December) }\end{array}$ & $\begin{array}{l}\text { Summer correlation } \\
\text { (April to September) }\end{array}$ & $\begin{array}{r}\text { Winter and spring correlation } \\
\text { (October to March) }\end{array}$ \\
\hline \multicolumn{4}{|c|}{ (a) Hunza climate stations } \\
\hline \multicolumn{4}{|l|}{ Precipitation } \\
\hline Khunjerab & $0.26(0.17)$ & $0.17(0.11)$ & $\mathbf{0 . 1 0}(0.00)$ \\
\hline Ziarat & $0.02(0.05)$ & $-0.01(0.01)$ & $0.02(0.02)$ \\
\hline Naltar & $0.03(0.02)$ & $-0.04(-0.01)$ & $-0.01(-0.05)$ \\
\hline $\begin{array}{l}\text { Avg. of Hunza basin } \\
\text { climate stations }\end{array}$ & $0.08(0.08)$ & $-(0.04)$ & $0.01(-0.04)$ \\
\hline Winter precipitation & & Summer stream flow & \\
\hline (Oct-Mar) & & $(\mathrm{Apr}-\mathrm{Sep})$ & \\
\hline Khunjerab & - & $0.12(0.06)$ & \\
\hline Ziarat & - & $0.08(0.06)$ & \\
\hline Naltar & - & $\mathbf{0 . 0 7}(0.00)$ & \\
\hline $\begin{array}{l}\text { Avg. of Hunza basin } \\
\text { climate stations }\end{array}$ & & $\mathbf{0 . 1 0}(0.03)$ & \\
\hline \multicolumn{4}{|l|}{ Daily mean temperature } \\
\hline Khunjerab & $0.79(0.69)$ & $0.80(0.66)$ & $0.64(0.36)$ \\
\hline Ziarat & $0.79(0.67)$ & $0.81(0.66)$ & $0.61(0.32)$ \\
\hline Naltar & $0.77(0.66)$ & $0.73(0.56)$ & $0.64(0.36)$ \\
\hline $\begin{array}{l}\text { Avg. of Hunza basin } \\
\text { climate stations }\end{array}$ & $0.79(0.69)$ & $0.81(0.66)$ & $0.65(0.36)$ \\
\hline \multicolumn{4}{|c|}{ (b) Gilgit climate station } \\
\hline Precipitation & $0.04(\mathbf{0 . 1})$ & $-0.22(-0.1)$ & $-0.01(-0.18)$ \\
\hline $\begin{array}{l}\text { Winter precipitation } \\
\text { (Oct-Mar) }\end{array}$ & - & $-0.04(-0.06)$ & \\
\hline Daily mean temperature & $0.79(0.68)$ & $0.89(0.81)$ & $0.70(0.26)$ \\
\hline
\end{tabular}

Values outside and within the ( ) are Pearson and Kendall rank correlation coefficient values, respectively. Bold figures: values are different from 0 with $p=0.05$.

The regression analysis results presented in Table 5 suggest that zone $\mathrm{C}$ (corresponding to the Khunjerab climate station) is the most active hydrological zone for Hunza River flows. Both the correlation coefficient values for precipitation and mean temperature at Khunjerab and runoff at Dainyor are higher than or equal to other catchment stations (Naltar and Ziarat). This result can also be observed in Fig. 5, where zone B (corresponding to the Ziarat climate station) and zone $\mathrm{C}$ (corresponding to the Khunjerab climate station) present a significant contribution to river flow in the form of snow melt in summer (April to September). Zone $\mathrm{C}$ has the largest proportion (64\%) of the Hunza basin area as given in Table 2 and hence a small drop in the percentage of snow cover in zone $\mathrm{C}$ in summer will have a significant impact on catchment runoff.

\subsection{Snow cover dynamics in the Hunza River basin}

MODIS image analysis for snow cover dynamics over a 10yr period suggests that the cryosphere area in the Hunza River basin has an increasing tendency (though the trend is not statistically significant), as shown in Fig. 5. Analysis of Kendall's tau $(\tau)$ coefficient value indicates an upward tendency of the snow cover area in zone $\mathrm{C}$ over an elevation of $4300 \mathrm{~m}$. This tendency is stronger in the maximum snow periods from November to February in all the altitudinal zones, notably in zone $\mathrm{C}(\tau=0.25)$ (Fig. 5). In the minimum snow cover periods from June to September, a slight increasing trend is noted in zone $\mathrm{C}(\tau=0.02)$ (Fig. 5); this expansion may result from the constancy in the mean temperatures and an increasing trend in the catchment's annual precipitation. Fowler and Archer (2006) found that summer temperatures (July to September) which are the key for glacial melt, have been falling at many valley stations in the Karakoram in the 


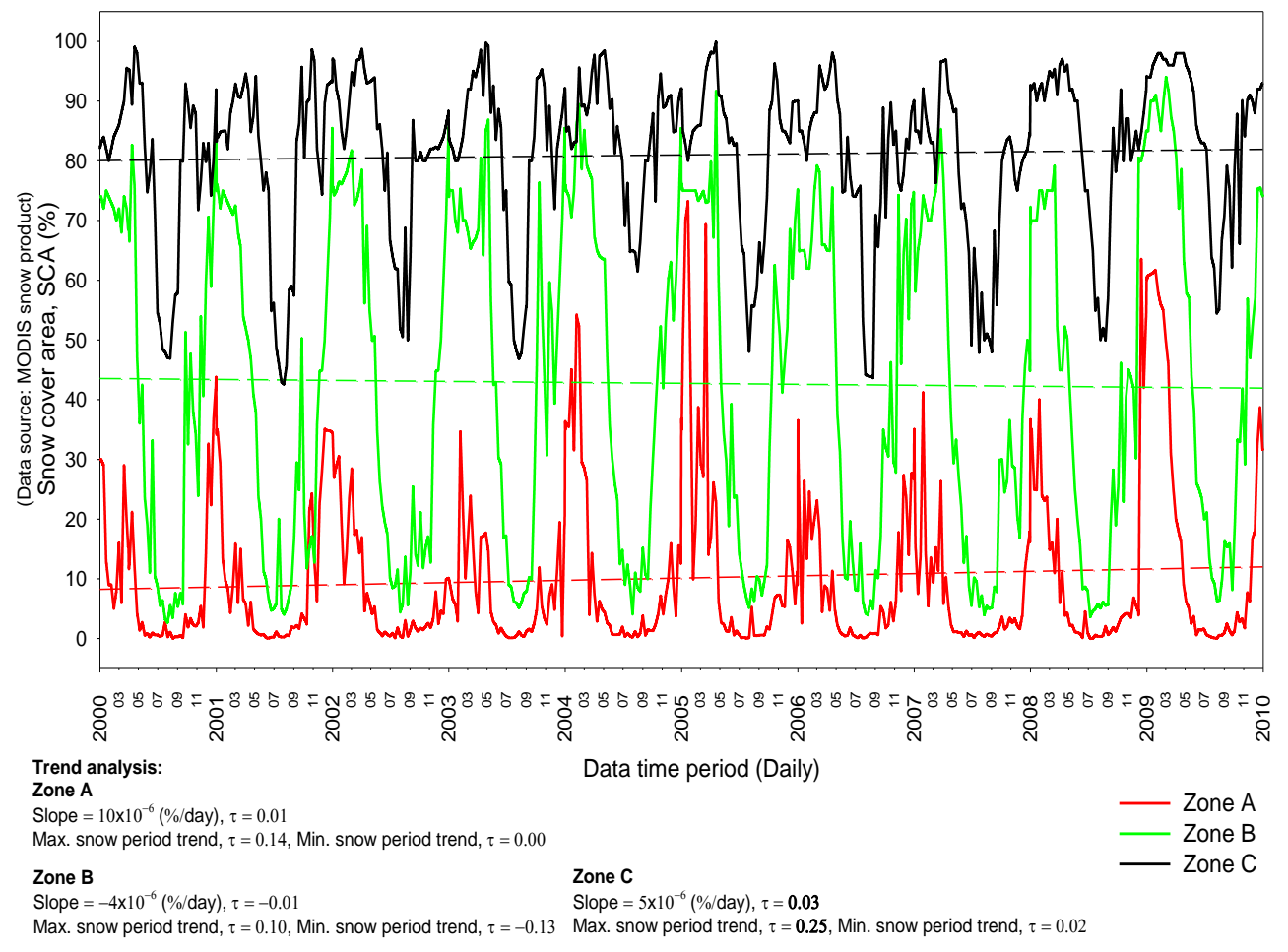

Fig. 5. Snow cover distribution in three different altitudinal zones of the Hunza River basin. Increasing trend (though not significant) can be noted in zone C. Seasonal Mann Kendall's trend analysis is also presented for maximum (November-February) and minimum (JuneSeptember) snow cover periods. (Kendall's tau $(\tau)$ coefficient values presented in bold figures indicate an increasing trend with $p<0.05$ ).

period 1961 to 2000. Hussain et al. (2005) indicated similar temperature falls in the monsoon and pre-monsoon period for the high mountain regions. In addition, a significant increase in the precipitation is reported in the Upper Indus Basin in both winter and summer during the period 19611999 (Archer and Fowler, 2004).

The increasing trends of precipitation continue to feed the high altitudes, particularly zone $\mathrm{C}$, and results in the form of expanding snow cover in the area. A greater proportion of the catchment area (i.e. almost $32.5 \%$ of the catchment area) is higher than $5000 \mathrm{~m}$ in elevation, as shown in Fig. 3 and presented in Table 1 and nearly the same percentage of area $(30 \%-40 \%)$ is snow covered all year, as illustrated by the snow cover distribution in Fig. 6. This is the area where the mean temperature remains below freezing throughout the year and the snow cover is expanding as a result of the increasing precipitation trend. This snow cover area expansion may be associated to the glacier advancing (especially surging) as reported by different researchers as follows. Hewitt $(2005,2007)$ found that in the late 1990s there was widespread evidence of glacier advancing mainly in high level glaciers in the central Karakoram. Analysing the response of Himalayan glaciers to the climate change, Scherler et al. (2011) has found that more than $50 \%$ of the glaciers observed in the Karakoram region (westerliesinfluenced) are advancing or stable in contrast to the retreat- ing glaciers of eastern Himalaya (monsoon-influenced) and Tibetan Plateau. Research on glacial mass balance in the central Karakoram region by Hewitt $(1998,2005)$ on the basis of extensive field experience over several decades also contrast with reports elsewhere of shrinking glaciers. The longer records of climate data at high-altitude weather stations and satellite images may help researchers to understand the dynamics of snow cover in the area. In the future, automatic weather stations or snow pillows should be installed over $5000 \mathrm{~m}$ in elevation to assess the precipitation patterns in the most active hydrological zone of the Karakoram Range (WAPDA, personal communication, 2009).

The current hypothesis for this phenomenon of increasing cryosphere area is an increase in winter precipitation mainly due to westerly circulation, as explained by Hewitt (2005) and Archer and Fowler (2004). The impact of global warming is not noticeable because of the high altitudes in the Hunza River basin. Even if global warming is real, the mean temperature remains negative or very low over a large part of the basin area. The increasing precipitation in the form of snowfall continues to feed the snow cover and the accumulation zones of glaciers in zones B and C. 


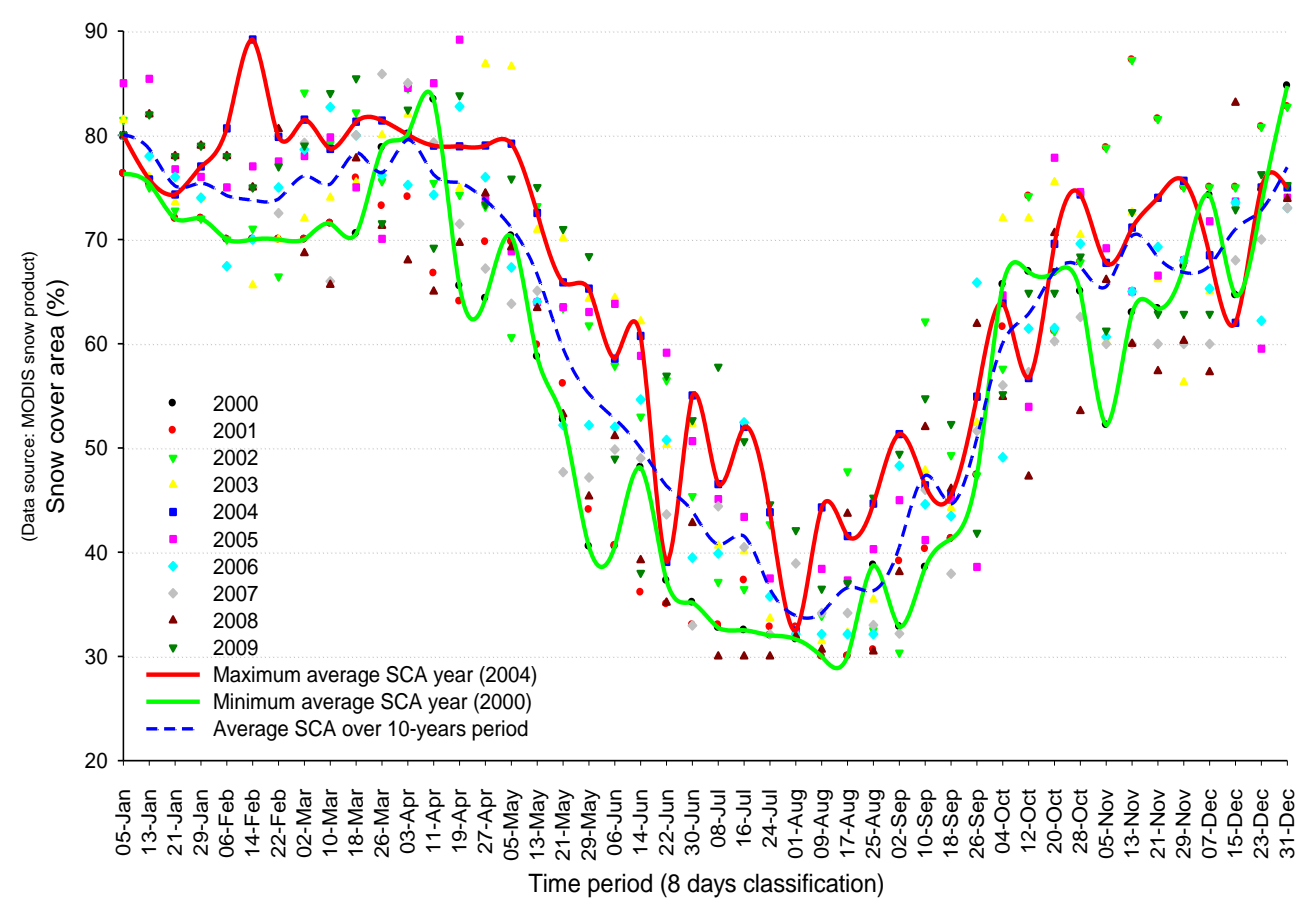

Fig. 6. Percentage snow cover area (SCA) in the Hunza River basin calculated by analysing 450 MODIS (MOD10A2) images.

\subsection{Correlation between snow cover change, climate variables and stream flow in the Hunza River basin}

Snow cover in the area is at a maximum $70-80 \%$ in the winter and spring seasons (December to April) and at a minimum $30-40 \%$ in the summer (July to September), as shown in Fig. 6. This change in the snow cover has a significant inverse correlation with the mean temperatures and discharge in the Hunza River basin, as shown in Fig. 7 and Table 6. The relationship between standardised values of four variables (precipitation, snow cover, mean temperature and discharge) is presented in Fig. 7. The values were standardised using the normal deviate formula, i.e. the distance of one data point from the mean, divided by the standard deviation of the distribution. This indicates a continuous depletion in the snow cover in summer as the average temperature in the area increases, resulting in increasing discharge. In winter, as the temperature decreases, the snow cover starts to increase and hence discharge decreases. The monthly difference in the Hunza River discharge at Dainyor is inversely correlated (Pearson's correlation coefficient $=-0.73$; Kendall's rank correlation $=-0.56$ ) with the monthly difference in the snow cover, as shown in Fig. 8, which indicates that the change in Hunza River discharge is dependent on the snow cover change in the area. It is likely that the large snow cover difference has a large impact on discharges because a larger snow cover area may also result in higher snow depths (at least in low-slope areas).
Pearson and Kendall's rank correlation coefficient values $(p=5 \%)$ were used to evaluate the correlation between the snow cover change and (a) climate variables (the mean temperature, precipitation) and (b) stream flow in the Hunza River, as given in Table 6. There are more variables which influence the river runoff (e.g. evaporation, sublimation, melting permafrost, different ablation procedures on debris covered or debris free glaciers) but these have not been taken into consideration in this study. These variables become important when applying a theoretical hydro-climatic model of mountain systems. No significant correlation was found between the snow cover change and precipitation in the Hunza basin. This may be due to the fact that the precipitation gauges are mostly under sampled in the high-altitude catchments due to a number of errors, as explained by Førland et al. (1996) and therefore cannot efficiently represent the snow cover change at high altitudes. The maximum inverse correlation was found between the snow cover change in the Hunza basin and the mean temperatures observed at Khunjerab and Ziarat. A high significant inverse correlation was found between snow cover change and summer and annual discharges (Table 6). This correlation indicates that the stream flow in the Hunza River strongly depends on the snow cover change and the mean temperatures in the catchment. This is in accordance with the result found by the Bookhagen and Burbank (2010) that the western Himalayan catchments (e.g. Indus River catchment) are fed by the snowmelt up to $50 \%$ as a fraction of the total annual discharge. 
Table 6. Annual and seasonal correlation coefficients between snow cover change, Hunza River basin (2000-2008), and a) daily climate data (precipitation and temperature) (2000-2008), b) daily stream flow data at Dainyor bridge (2000-2008).

\begin{tabular}{|c|c|c|c|}
\hline \multirow[t]{2}{*}{ Climate data } & \multicolumn{3}{|c|}{ Snow cover change in the Hunza River basin } \\
\hline & $\begin{array}{r}\text { Annual correlation } \\
\text { (January to December) }\end{array}$ & $\begin{array}{l}\text { Summer correlation } \\
\text { (April to September) }\end{array}$ & $\begin{array}{r}\text { Winter and spring correlation } \\
\text { (October to March) }\end{array}$ \\
\hline \multicolumn{4}{|l|}{ (a) Hunza climate stations } \\
\hline \multicolumn{4}{|l|}{ Precipitation } \\
\hline Khunjerab & $-0.26(-0.18)$ & $-0.17(-0.11)$ & $-0.09(-0.09)$ \\
\hline Ziarat & $-0.02(-0.05)$ & $-0.01(-0.03)$ & $0.04(0.01)$ \\
\hline Naltar & $-0.01(-0.02)$ & $\mathbf{0 . 0 7}(0.02)$ & $0.01(0.00)$ \\
\hline Avg. of Hunza basin climate stations & $-0.07(-0.08)$ & $0.01(-0.04)$ & $0.01(-0.01)$ \\
\hline \multicolumn{4}{|l|}{ Daily mean temperature } \\
\hline Khunjerab & $-0.80(-0.56)$ & $-0.78(-0.56)$ & $-0.42(-0.21)$ \\
\hline Ziarat & $-0.80(-0.57)$ & $-0.80(-0.57)$ & $-0.43(-0.25)$ \\
\hline Naltar & $-0.78(-0.54)$ & $-0.72(-0.48)$ & $-0.40(-0.21)$ \\
\hline Avg. of Hunza basin climate stations & $-0.80(-0.56)$ & $-0.80(-0.56)$ & $-0.43(-0.23)$ \\
\hline (b) Stream flow & $-0.88(-0.65)$ & $-0.81(-0.68)$ & $-0.64(-0.26)$ \\
\hline
\end{tabular}

Values outside and within the ( ) are Pearson and Kendall rank correlation coefficient values, respectively. Bold figures: values are different from 0 with $p=0.05$.

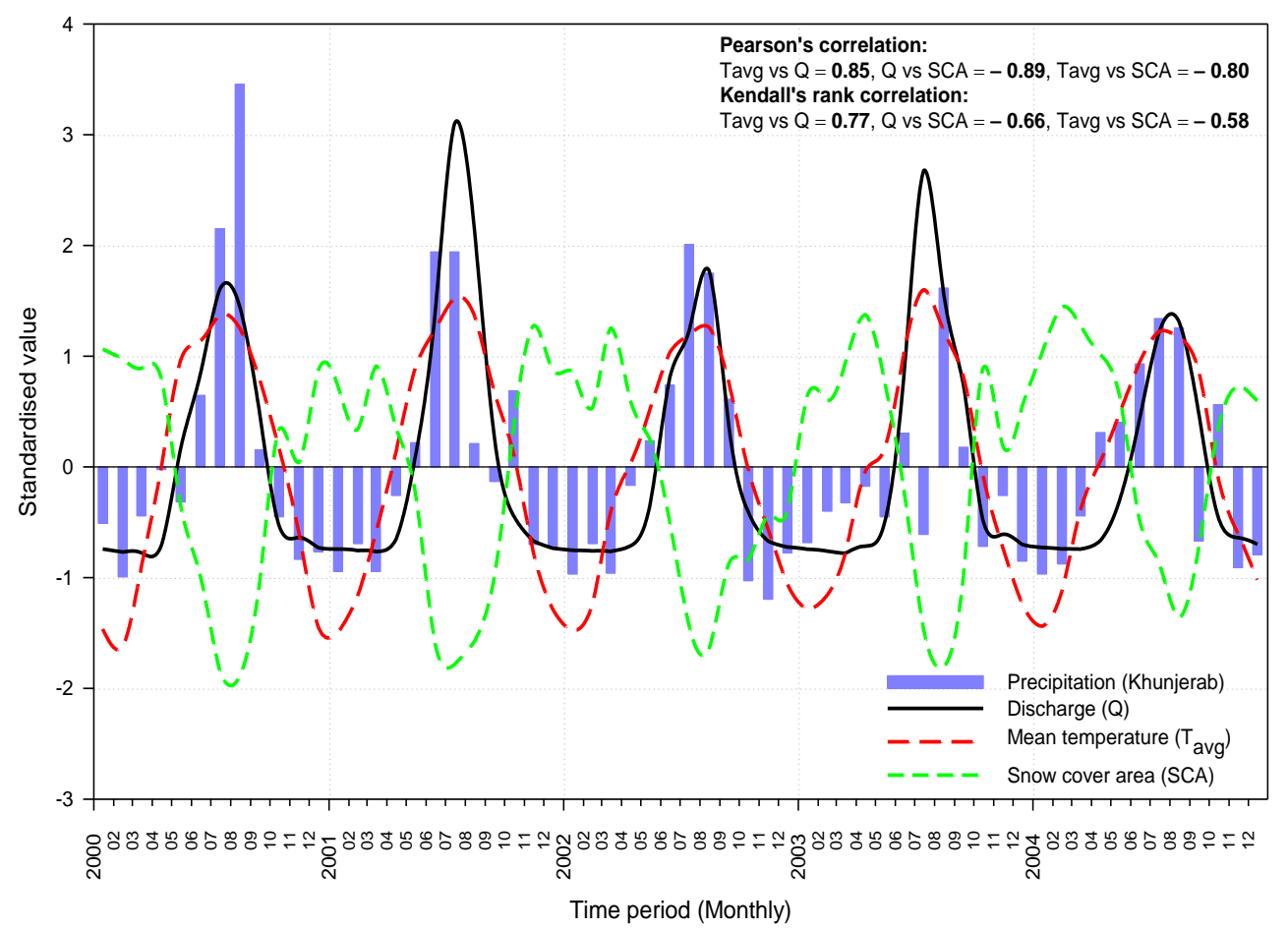

Fig. 7. Correlation between standardised values of precipitation (Khunjerab), snow cover, average temperature and discharge (at Dainyor) in the Hunza River basin (on a monthly basis). All the correlation values are significant with a significance level, $p<0.05$.

The analysis of $25 \mathrm{yr}$ of flow records (1980-2004) for the Hunza River shows that the annual flow decreases with time, as shown in Fig. 9. In contrast to the precipitation data of Hunza River basin, the discharge data at Dainyor Bridge is available over a long period and the quality of data is quite reliable. With shorter time-series, (Archer and Fowler, 2004) associated the decreasing river discharges of the high-altitude central Karakoram catchments with the long-term storage of additional ice. 


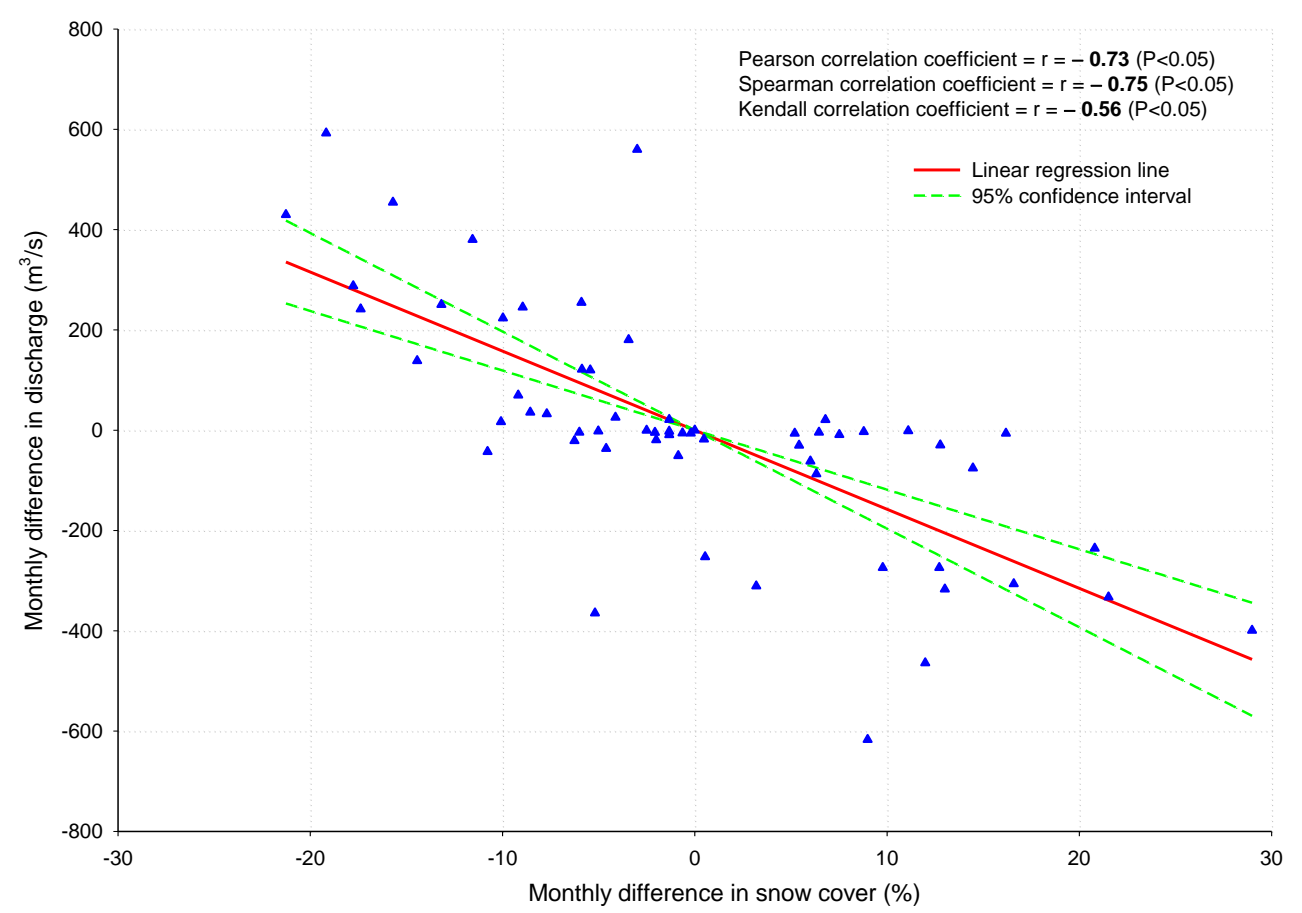

Fig. 8. Correlation between monthly difference in snow cover and monthly difference in discharge at Dainyor in the Hunza River basin. All the correlation values are significant with a significance level, $p<0.05$.

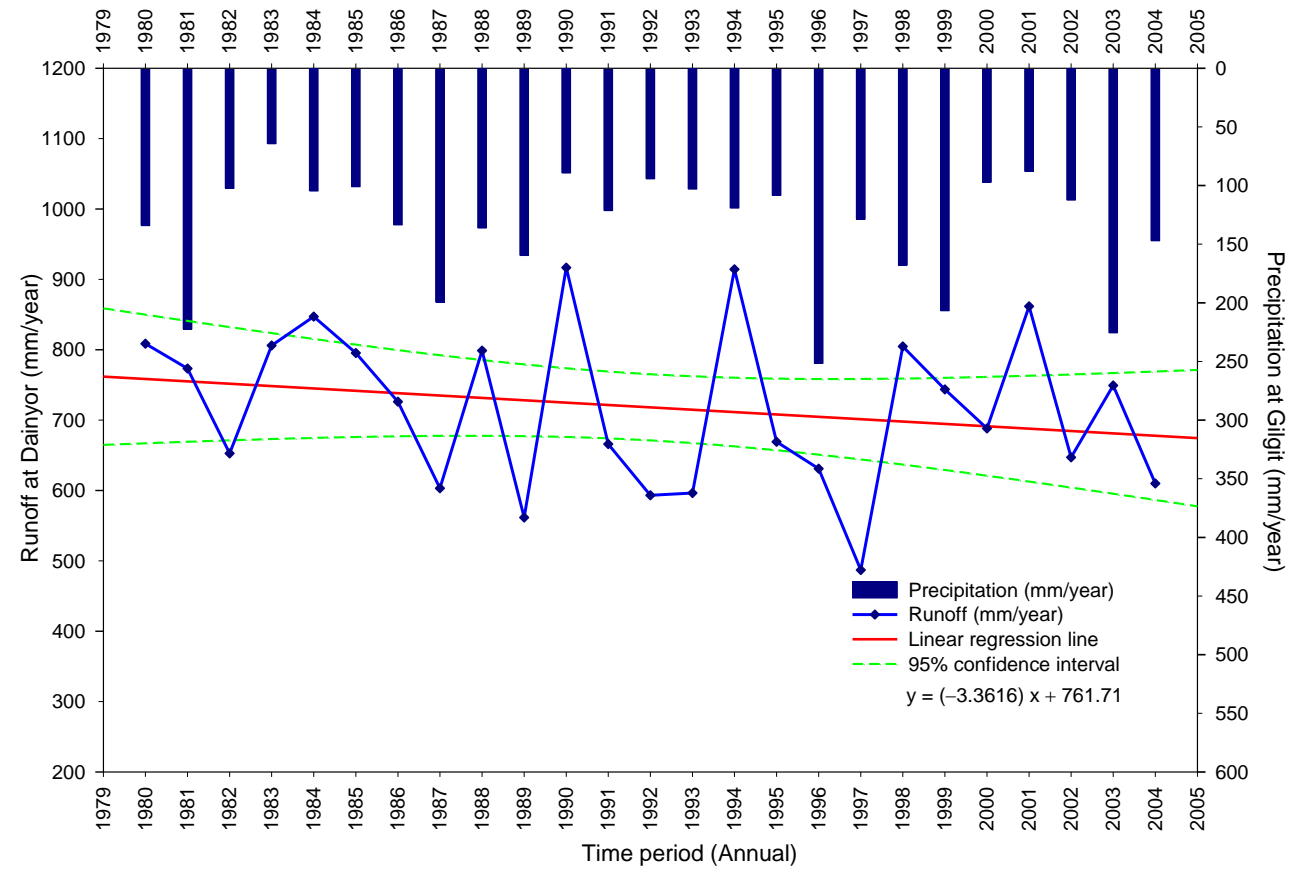

Fig. 9. Annual flow trend in Hunza River at Dainyor Bridge and total annual precipitation at Gilgit over 25 yr (1980-2004).

\section{Conclusions}

The Hunza River basin is one of the main tributaries of the Indus river irrigation system that contributes nearly one-fifth of the Upper Indus flow at Partab Bridge. Situated in the high- elevation zone of central Karakoram, the Hunza river flow depends mainly on the accumulation of snow at high altitudes and energy input indirectly related to temperature. This suggests that meteorological data collection methods should be improved at the high-altitude stations present within the 
basin area to study the snow cover and runoff controlling factors more effectively. The following conclusions can be drawn by analysing the results obtained in this study:

- The climate stations present within the Hunza River catchment area may be used to study the behaviour of stream flow at Dainyor Bridge in the future.

- MOD10A2 remote sensing cryosphere product is a very valuable product and will greatly enhance the hydrological predictions in the remote areas. In addition, MODIS MOD10A2 product is free of charge and easy to treat and therefore is a good option to assess the percentage cryosphere areas in the Hunza and other remote sub-catchments of UIB over the long term. However, there are some errors and uncertainties associated to this product; for example, it has a larger mismatch with higher-spatial resolution ASTER images on low elevation regions with higher relief.

- The stream flow in the Hunza River is influenced mainly by winter precipitation, but also by the mean summer and winter temperatures of its catchment. Moreover, the most active hydrological region of the Hunza River basin seems located above an elevation of $4500 \mathrm{~m}$ in zone $\mathrm{C}$.

- The 10-yr analysis of the remotely sensed cryosphere data and a declining discharge trend in the Hunza River observed in this study, in combination with the research of Archer and Fowler (2004), Hewitt (2005) and Fowler and Archer (2006) who show an increasing winter precipitation trend and a decreasing trend in summer mean temperatures, suggest that the Hunza River basin is a region undergoing a slight expansion in the cryosphere area, especially at high elevations.

- The study of annual and seasonal snow cover suggests that the snow cover change has a highly inverse correlation with the catchment's summer mean temperatures, which results in a large amount of stream flow. Therefore, it is very important to estimate the winter snow accumulations (November to February) at high altitudes to forecast the peak summer flow (May to September) and ultimately to improve the management of the Tarbela reservoir.

A detailed study is needed on the other high-altitude catchments of the Upper Indus region (e.g. Shigar and Shyok) that contribute a substantial amount of flow to the Indus River and are mainly snow- and glacier-fed. The combination of satellite snow cover data and ground data (e.g. snow-pits) or information based on snow cover-runoff models is an appropriate approach to overcome the poor gauging of precipitation data at these high altitudes. Snow depletion curves calculated in this study for each altitudinal zone of the Hunza River basin can further be used (after a critical evaluation), as input to the hydrological models with a snow component, e.g. the Snowmelt Runoff Model developed by Martinec (1975), to simulate and forecast the stream flow at Dainyor Bridge as well as to study the climate change impact on snow cover and stream flow dynamics in the future. Ultimately, this study will help to improve integrated water resource management in the Tarbela reservoir.

Acknowledgements. Adnan Ahmad Tahir was financially supported by the Higher Education Commission of Pakistan within the framework of a France-Pakistan collaboration program for overseas studies. This financial support is gratefully acknowledged and appreciated. The authors extend their thanks to the Water and Power Development Authority (WAPDA) and the Pakistan Meteorological Department (PMD) for contributing their hydrological and meteorological data, respectively. The authors also wish to thank NASA and Japan's Ministry of the Economy, Trade and Industry (METI) for providing ASTER GDEM and to the Global Land Ice Measurements from Space (GLIMS) project for providing four ASTER images for glacier and snow cover estimation. The authors also acknowledge the anonymous reviewers for their valuable, rigorous and scrupulous comments, which considerably improved the content of this manuscript.

Edited by: P. Molnar

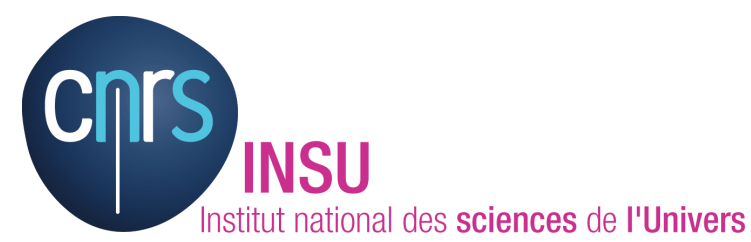

The publication of this article is financed by CNRS-INSU.

\section{References}

Akhtar, M., Ahmad, N., and Booij, M. J.: The impact of climate change on the water resources of Hindukush-KarakorumHimalaya region under different glacier coverage scenarios, J. Hydrol., 355, 148-163, doi:10.1016/j.jhydrol.2008.03.015, 2008.

Archer, D.: Contrasting hydrological regimes in the Upper Indus Basin, J. Hydrol., 274, 198-210, doi:10.1016/S00221694(02)00414-6, 2003.

Archer, D. R. and Fowler, H. J.: Spatial and temporal variations in precipitation in the Upper Indus Basin, global teleconnections and hydrological implications, Hydrol. Earth Syst. Sci., 8, 4761, doi:10.5194/hess-8-47-2004, 2004.

Berthier, E., Arnaud, Y., Kumar, R., Ahmad, S., Wagnon, P., and Chevallier, P.: Remote sensing estimates of glacier mass balances in the Himachal Pradesh (Western Himalaya, India), Remote Sens. Environ., 108, 327-338, doi:10.1016/j.rse.2006.11.017, 2007.

BGIG: Investigation report on the Batura glacier in the Karakoram Mountains, the Islamic Republic of Pakistan (1974-1975), Beijing, 1976. 
Bookhagen, B. and Burbank, D. W.: Toward a complete Himalayan hydrological budget: Spatiotemporal distribution of snowmelt and rainfall and their impact on river discharge, J. Geophys. Res., 115, F03019, doi:10.1029/2009JF001426, 2010.

Dankers, R. and de Jong, S. M.: Monitoring snow cover dynamics in Northern Fennoscandia with SPOT vegetation images, Int. J. Remote Sens., 25, 2933-2949, 2004.

Førland, E. J., Allerup, P., Dahlström, B., Elomaa, E., Jónsson, T., Madsen, H., Perälä, J., Rissanen, P., Vedin, H., and Vejen, F.: Manual for operational correction of Nordic precipitation data, DNMI, P.O. Box 43, Blindern, Oslo, Norway, 24/96, 66, 1996.

Fowler, H. J. and Archer, D. R.: Hydro-climatological variability in the Upper Indus Basin and implications for water resources, Regional Hydrological Impacts of Climatic Change - Impact Assessment and Decision making, Seventh IAHS Scientific Assembly at Foz do Iguaçu, Brazil, 131-138, 2005.

Fowler, H. J. and Archer, D. R.: Conflicting signals of climatic change in the Upper Indus Basin, J. Climate, 19, 4276-4293, 2006.

Hall, D., Riggs, G., Salomonson, V. V., DiGirolamo, N., and Bayr, K.: Modis snow-cover products, Remote Sens. Environ., 83, 181-194, 2002.

Hall, D., Riggs, G., and Salomonson, V.: Modis/terra snow cover 8day 13 global 500m grid v005, [March 2000 to December 2009], in: Boulder, Colorado USA: National Snow and Ice Data Center, Digital media, updated weekly, 2006.

Haritashya, U. K., Bishop, M. P., Shroder, J. F., Bush, A. B. G., and Bulley, H. N. N.: Space-based assessment of glacier fluctuations in the Wakhan Pamir, Afghanistan, Climatic Change, 94, 5-18, 2009.

Hewitt, K.: Snow and ice hydrology project, Wilfrid Laurier University, Waterloo, Ontario, 1986.

Hewitt, K.: Glaciers receive a surge of attention in the Karakoram Himalaya, Eos, Transactions American Geophysical Union, 79, 104-105, 1998.

Hewitt, K.: Hazards of melting as an option: Upper Indus glaciers i \& ii, in: Dawn, 2001.

Hewitt, K.: The Karakoram anomaly? Glacier expansion and the elevation effect, Karakoram Himalaya, Mt. Res. Dev., 25, 332340, 2005.

Hewitt, K.: Tributary glacier surges: An exceptional concentration at Panmah Glacier, Karakoram Himalaya, J. Glaciol., 53, 181$188,2007$.

Hewitt, K., Wake, C. P., Young, G. J., and David, C.: Hydrological investigation at Biafo Glacier, Karakoram range, Himalaya; an important source of water for the Indus river, Ann. Glaciol., 13, 103-108, 1989.

Hirsch, R. M. and Slack, J. R.: A nonparametric trend test for seasonal data with serial dependence, Water Resour. Res., 20, 727732,1984

Hirsch, R. M., Slack, J. R., and Smith, R. A.: Techniques of trend analysis for monthly water quality data, Water Resour. Res., 18, 107-121, 1982.

Hussain, S. S., Mudasser, M., Sheikh, M. M., and Manzoor, N.: Climate change and variability in mountain regions of Pakistan: Implications for water and agriculture, Pakistan Journal of Meteorology, 2, 79-94, 2005.

Immerzeel, W. W., Droogers, P., de Jong, S. M., and Bierkens, M. F. P.: Large-scale monitoring of snow cover and runoff simulation in Himalayan river basins using remote sensing, Remote Sensing of Environment, 113, 40-49, doi:10.1016/j.rse.2008.08.010, 2009.

IPCC: Climate change 2007: Synthesis report, Contribution of working groups i, ii and iii to the fourth assessment report of the Intergovernmental Panel on Climate Change, edited by: Pachauri, R. K and Reisinger, A., Intergovernmental Panel on Climate Change (IPCC), Geneva, Switzerland, 104, 2007.

Kendall, M. G.: Rank correlation measures, 4th Edn., Charles Griffin, London, 202 pp., 1975.

Kendall, M. G. and Gibbons, J. D.: Rank correlation methods, 5th Edn., Edward Arnold, London, 1990.

Lee, S., Klein, A. G., and Over, T. M.: A comparison of MODIS and NOHRSC snow-cover products for simulating stream flow using the snowmelt runoff model, Hydrol. Process., 19, 29512972, doi:10.1002/hyp.5810, 2005.

Liniger, H., Weingartner, R., and Grosjean, M.: Mountains of the world: Water towers for the 21 st century, in: Mountain agenda for the commission on sustainable development (CSD), BO12, Berne, 32, 1998.

Lopez, P.: Impact de la variabilité climatique sur la cryosphere du Campo de Hielo Norte: Apport de la télédétection, Doctorat, Systèmes Intégrés en Biologie, Agronomie, Géosciences, Hydrosciences, Environnement, Université Montpellier 2, Sciences et Techniques du Languedoc, Montpellier, 143 pp., 2007.

Martinec, J.: Snowmelt-runoff model for stream flow forecasts, Nord. Hydrol., 6, 145-154, 1975.

Maurer, E. P., Rhoads, J. D., Dubayah, R. O., and Lettenmaier, D. P.: Evaluation of the snow-covered area data product from Modis, Hydrol. Process., 17, 59-71, doi:10.1002/hyp.1193, 2003.

Mercer, J. H.: Glaciers of the Karakoram. In: W. O. Field mountain glaciers of the northern hemisphere., in, CRREL, Hanover New Hampshire, 371-409, 1975.

METI and NASA: ASTER Global Digital Elevation Model (GDEM), available at: http://www.ersdac.or.jp/GDEM/E/2.html, last access: November 2009, 2009.

Nagler, T., Rott, H., Malcher, P., and Müller, F.: Assimilation of meteorological and remote sensing data for snowmelt runoff forecasting, Remote Sens. Environ., 112, 1408-1420, 2008.

Rodgers, J. L. and Nicewander, W. A.: Thirteen ways to look at the correlation coefficient, The American Statistician, 42, 59-66, 1988.

Sarwar, A. and Bill, R.: Estimation of heat fluxes in the Indus basin using ASTER imagery, Pak. J. Water Resour., 7, 53-64, 2003.

Scherler, D., Bookhagen, B., and Strecker, M. R.: Spatially variable response of Himalayan glaciers to climate change affected by debris cover, Nat. Geosci., 4, 156-159, doi:10.1038/NGEO1068, 2011.

Sevruk, B.: Correction of precipitation measurements, Workshop on the Correction of Precipitation Measurements, Zurich, Switzerland, 13-23, 1985.

Sevruk, B.: Reliability of precipitation measurement, International Workshop on Precipitation Measurement, 13-19, 1989.

Sicart, J. E., Wagnon, P., and Ribstein, P.: Atmospheric controls of the heat balance of zongo glacier $\left(16^{\circ} \mathrm{S}\right.$, Bolivia), J. Geophys. Res., 110 (D12), D12106, doi:10.1029/2004JD005732, 2005.

Sicart, J. E., Pomeroy, J. W., Essery, R. L. H., and Bewley, D.: Incoming longwave radiation to melting snow: Observations, sensitivity and estimation in northern environments, Hydrol. Pro- 
cess., 20, 3697-3708, doi:10.1002/hyp.6383, 2006.

SIHP: Snow and ice hydrology project, Upper Indus River Basin, WAPDA-IDRC-Wilfrid Laurier University, 179, 1990.

Sirguey, P., Mathieu, R., and Arnaud, Y.: Improving Modis spatial resolution for snow mapping using wavelet fusion and arsis concept, IEEE Geosci. Remote Sens. Lett., 5, 2008.

Sirguey, P., Mathieu, R., and Arnaud, Y.: Subpixel monitoring of the seasonal snow cover with Modis at $250 \mathrm{~m}$ spatial resolution in the Southern Alps of New Zealand: Methodology and accuracy assessment, Remote Sens. Environ., 113, 160-181, 2009.

Tekeli, A. E., Akyürek, Z., Arda Sorman, A., Sensoy, A., and Ünal Sorman, A.: Using Modis snow cover maps in modeling snowmelt runoff process in the eastern part of Turkey, Remote Sens. Environ., 97, 216-230, 2005.
Vauchel, P.: Hydraccess in, 4.2 Edn., Institute of Research for Developement, France, 2005.

Wake, C. P.: Glaciochemical investigations as a tool to determine the spatial variation of snow accumulation in the central Karakoram, Northern Pakistan, Ann. Glaciol., 13, 279-284, 1989.

Winiger, M., Gumpert, M., and Yamout, H.: KarakoramHindukush-Western Himalaya: Assessing high-altitude water resources, Hydrol. Process., 19, 2329-2338, doi:10.1002/hyp.5887, 2005.

Young, G. J. and Hewitt, K.: Hydrology research in the Upper Indus Basin, Karakoram Himalaya, Pakistan, Hydrology of Mountanous Areas, Czechoslovakia, 139-152, 1990. 